\title{
The Four Problems which Old Testament Married Couples Grapple with
}

As it begins to reflect on man, the Holy Scripture places him in the context of marriage. In both stories about the creation of the world in the early passages of the Bible - Genesis 1 (authored by the sacerdotal class) and Genesis 2 (authored by the non-sacerdotal class) - the creation of man is de facto a creation of the first marriage. In biblical, dogmatic, moral or pastoral theology, these normative texts are treated as a biblical norm of the institution of matrimonium. Meanwhile, "normality" was different, and it is only against its backdrop that the profound novum addressed in the above-mentioned works emerges. In the present article I will discuss the main - in my opinion - difficulties that biblical

1 Marcin Majewski - theologian, biblical scholar, lecturer of the Bible, biblical archeology and Hebrew language at several Cracow universities, among others at the Pontifical University of John Paul II. He is an active member of 6 national and international scientific societies. He runs scientific projects funded by the National Science Center and other scientific intitutions. Author of several books and dozens of scientific articles. Co-editor of Orygenes.pl. Guide to the Holy Land. E-mail: marcin.majewski@upjp2.edu.pl. 


\section{Marcin Majewski}

married couples were faced with in the First Testament. ${ }^{2}$ These are: polygamy, lack of progeny, infidelity and divorce. Everyday life of biblical married couples is not only about דחא רשבל ויה, that is "they become one flesh" (Gen 2:24); it is also about numerous woes afflicting them. The contemporary crisis of the traditional model of marriage and the lively debate on Pope Francis' apostolic exhortation Amoris Laetitia make us take a closer look also at this difficult aspect of matrimony in the context of biblical texts.

\section{Polygamy, or marrying multiple spouses}

More often than not, whenever the subject of asymmetrical marital relationships is raised, it is used to refer to polygyny; this term constitutes only part of the concept of polygamy. It relates to having multiple wives, that is a relationship between one man and several women. It does not take into account polyandry - the opposite situation - whereby one woman is in a marital relationship with several men, e.g. brothers. In other words, what we usually mean by "polygamy," or "having several spouses," is polygy ny, that is a marital relationship between one man and two or more women. Less frequently do we take into consideration polyandry - having several husbands - that is a marital relationship between a woman and more than one man. Over the course of history the phenomenon of polyandry has been much rarer than the one of polygyny. The Bible features frequent cases of polyandry, but only in the successive form, that is after the demise of the first husband, and

2 There is an ongoing debate regarding the name of the first part of the Christian Bible. Today, the phrase "Old Testament" may be construed as pejorative, especially in ChristianJewish dialogue, or while taking into account the perspective of Jesus and the first Church. Therefore, the terms "First Testament" and "Second Testament" are preferable. Still, it is easy to see that in such a case the term "second" is not neutral either. Thus, I choose the terms "First Testament" and "New Testament". The term "First Testament" - instead of "Old Testament" - is more and more readily accepted by biblical scholars on account of its nondeprecatory approach to the value of the said part of the Bible, which might be the case when the term "old" is used alongside "new". 
never in the actual, concurrent form. Therefore, it should be concluded that in the Bible the factual and actual polygamy is narrowed only to polygyny ${ }^{3}$.

The question of polygamy is interesting inasmuch as the average man deems it immoral and unacceptable, while in no place does the Holy Scripture explicitly condemn the phenomenon. The contemporary culture furnishes a crucial context in which to discuss the subject of polygamy. In the wake of the legal recognition of homosexual relationships and formalising other forms of partnerships follows a dynamic development of movements for legalisation of polygamy (e.g. the activity of the American organisation Pro-Polygamy, or the multi-year activity of a Swedish society for legalisation of polygamy). Adherents of these movements tend to invoke the fact that no biblical passage explicitly condemns polygamy, and that the patriarchs had two or more wives. There is a growing body of anthropological, biological and sociological research which indicates that polygamy is a natural phenomenon which in many cultures is even more frequent than monogamy, and so re-evaluation of the phenomenon is advocated ${ }^{4}$.

There is no doubt that normative texts on family in the Bible - like two descriptions of the creation of man (Gen 1:26n and 2:23n) - depict matrimonium as a monogamous relationship ${ }^{5}$. God made the male and the female equal, complementary creatures characterised by mutual attraction and called upon to forge a lasting bond. Both the vivid creation stories present - though in a different manner - the same truths about

3 C. Friedl, Polygynie in Mesopotamien und Israel: Sozialgeschichtliche Analyse polygamer Beziehungen anhand rechtlicher Texts aus dem 2. und 1. Jahrtausend v.Chr., Munster 2000, p. 19.

4 J.P. Burnside, Strange Flesh: Sex, Semiotics and the Construction of Deviancy in Biblical Law, "Journal for the Study of the Old Testament" 30 (2006), p. 403. See also H. R. Jacobus, Slave Wives and Transgressive Unions in Biblical and Ancient Near Eastern Laws and Literature, in: Leviticus and Numbers, ed. A. Brenner, A. Chi Chung Lee, Minneapolis 2013, p. 55-56; T. A. Salzman, M. G. Lawler, The Sexual Person: Towards a Renewed Catholic Anthropology, Washington 2008, p. 13.

5 See W. Gross, Die Gottebenbildlichkeit des Menschen nach Gen 1,26.27 in der Diskussion des letzten Jahrzehnts, "Biblische Notizen" 68 (1993), p. 35-48; Z. Kiernikowski, Dwoje jednym ciałem w Chrystusie, Warszawa 2000; Marriage and Family in the Biblical World, ed. K. M. Campbell, Downers Grove 2003; S. Bielecki, Stary Testament o małżeństwie. Ideał i rzeczywistość, "Kieleckie Studia Teologiczne” 2 (2003), p. 83-101; A. Schüle, Die Urgeschichte (Genesis 1-11), Zurich 2009 (Zürcher Bibelkommentare AT 1/1). 


\section{Marcin Majewski}

the marital relationship as the exclusive, indissoluble ("one flesh") and monogamous. The status becomes corrupted by sin. According to the biblical narrative, the first one to break the rule of monogamy and marry two women was Lamech, morally degenerate Cainite (Gen 4:19), who was even more depraved than Cain, his forefather (See Gen 4:23-24). It is no coincidence that the first mention of polygamy was made within the context of Lamech - icon of this depravity.

The biblical authors indicate that post-deluge people found polygamy - and most often bigamy - an acceptable practice. Having a mistress was also the norm. The Nuzi tablets (ca. $1500 \mathrm{BC}$ ) or the Code of Hammurabi (ca. $1700 \mathrm{BC}$ ), while restrictive on this issue, encourage a man to take a concubine or a mistress if his wife turns out to be barren. ${ }^{6}$ The then society fully approved of polygamy. It is noteworthy that the biblical patriarchs did try to have single and beloved wives only, the situation made them take advantage of the then acceptable polygamous status. On account of the necessity to have offspring, Abraham agreed to have concubine Hagar, and Jacob married two sisters, Rachel and Leah, having been tricked by Laban (See Gen 29:16-30). Furthermore, it was not against a wife's wish, but at her prompting or sometimes as a result of her intrigue that at a husband's side a concubine appeared, which points to a clear priority of having offspring over practising monogamy. Barren Sarah offered her handmaid Hagar, and barren Rachel - her handmaid Bilhah (Gen 30:3-8). Later on, Jacob's second wife Leah, for fear of not being able to bear another child, sent her handmaid Zilpah to his tent (Gen 30:9-13). In the times of the First Testament, sterility was viewed as disgrace, and from the practical perspective, it meant severance of the traditional inheritance pattern, lack of generational continuity and memory of the deceased, and last but not least - lack of care of the married couple when they are old?. In order to remedy the situa-

6 In antiquity the notion of man's sterility was unknown and as such was not taken into account; it was always the woman who was blamed for a lack of progeny. Today we know that the incidence of infertility is more or less evenly distributed between the sexes.

7 S. Shectman, Rachel, Leah, and the Composition of Genesis, in: The Pentateuch: International Perspectives on Current Research, eds. T. B. Dozeman, K. Schmid, B. J. Schwartz, Tübingen 2011, p. 207-222. 
tion, which was commonly found to be evil, some measures were taken with a view to allowing the man to beget, with a handmaid or even a harlot, children who were to be regarded as rightful heirs (which was regulated by the Code of Lipit-Ishtar). The possibility of employing a service of some kind of a surrogate mother was accepted in the society in which the position of a woman was measured by the number of children she afforded to the family.

The Bible offers more examples of polygamous men. Judge Gedeon had many wives (Judg 8:30). Likewise, King David - the biblical author lists the names of eight of them (See 2 Sam 3:2-5). The record-holder in this field is King Solomon, who - by the chronicler's account - had seven hundred wives of royal birth and three hundred concubines (1 Kgs 11:3). Having a harem was a symbol of the monarch's prestige, greatness and wealth, and in the event of a different sovereign ascending the throne, taking over the predecessor's harem by the new king served as a confirmation of the seizure of power (Cf. 2 Sam 12:8; 16:21n). Since a typical harem-based relationship used to revolve around service and occasional contact, the institution of harem leaves hardly any room for matrimony in the classical sense of the word. As regards Solomon, one more important factor comes into play - a political one. According to the biblical author, King Solomon's numerous marriages were above all of a diplomatic character. They served to confirm the alliances formed with the kings of Canaan and neighbouring kingdoms.

Although the biblical author gives an account of Solomon's many wives, he does not approve of the situation ${ }^{8}$. It is the polygamy that he blames for the downfall of the godly king and the beginning of the end of his great kingdom (1 Kgs 11:4-5). The Book of Ecclesiasticus's author bemoaned the downfall of this wise ruler (See Sir 47:14, 19). In the Book of Deuteronomy (Deut 17:14-20) the lawgiver points it out that the King... must not take many wives, or his heart will be led astray, and this provision resonates with the history of Solomon. And even though we do not have to interpret the law as God's imperative of monogamy, it is an attempt

8 J. F. Drinkard, An Understanding of Family in the Old Testament. Maybe not as Different from Us as We Usually Think, Review and Expositor 98 (2001) 498-499. 
at containing this eastern custom. This reveals a feature of the biblical vision of polygamy: the Scripture treats of a polygamous marriage only when it describes ancient stories. When it teaches about marriage and considers the institution from God's perspective - e.g. in texts about creation, prophetic paraeneses or wisdom proverbs - it always stresses a monogamous marriage.

People in the Bible were well aware of the fact that polygamy gave rise to numerous problems. This can be illustrated with a First Testament recurring thread of difficult relations between the wives of one man, e.g. Sarah, Hagar, Rachel and Leah, or Hannah and Penninah. The Hebrew language puts this relation bluntly, calling the second wife הרצ, which literally means a "rival," or a "contestant" (1 Sam 1:6). This was compounded by the economic issue of maintaining a larger number of wives, and, by extension, of raising an appropriately larger group of children, which was something that only a rich man could afford. Hence, even from a purely practical point of view, monogamy was more desirable and considerably more common. Arguably, the situation was similar to the one which we can observe among Bedouins and Fellahs in today's Palestine: despite the possibilities they are endowed with by the Islamic law, very rarely do they decide on polygamy. In fact, despite the above-mentioned examples of polygamy in the Bible, as early as the times of the First Testament, the majority of people practised marital monogamy, which remained the norm. Polygamy was a rarity, and most often was dictated by a custom (e.g. a royal one), or by a need to have offspring. The closer the times are to the New Testament, the rarer the phenomenon is.

Even when polygamy was a customary practice, the biblical authors presented monogamy as a plan most approximate to the only acceptable and devout marriage. God's intention was to join one man and one woman. From the very beginning, starting with Hosea in the $8^{\text {th }}$ century, the prophets likened God's relationship with Israel to the exclusive marital relationship. What sense would such a metaphor have if polygamy was an acceptable practice? God's wrath incurred by worship of His rivals would be irrational. The author of the Book of Proverbs many a time extols the marital exclusivity and fidelity of a monogamous relationship: "Drink water from your own cistern, running water from your own 
well..." (Prov 5:15-20; cf. Prov 31:10-31). ${ }^{9}$ The same teaching comes from Ecclesiastes (Eccl 9:9). The wisdom books frequently refer to the institution of marriage and do not take into consideration any other relationship, but only a relationship of one man and one woman, which finds its most profound expression in the lyrics of the Song of Songs.

To sum up, whenever the Bible describes everyday life of ancient people, it speaks about monogamous marriages and rare cases of polygamy, but when it teaches about matrimonium, the only option is monogamy. In the earlier texts of the Bible polygamy was condoned, but regulated. Only sororate marriages were prohibited, which was for practical reasons, as mentioned above (Lev 18:18). Following the Babylonian exile, in the times of the Second Temple, prophets and sages' teachings practically eliminated polygamy from the range of acceptable marriage forms. ${ }^{10}$

\section{Lack of Offspring. Sterility and Infertility}

Sterility means a permanent and irreversible inability to procreate progeny, e.g. as a result of an absence of ovaries in a woman, or testes in a man. On the other hand, infertility is a temporary (and at least in theory, overcomable) inability to have children. The context of the problem of infertility in the Bible is very topical. Today, many married couples long to have children, and yet despite all the efforts they make, a woman fails to become pregnant or carry a pregnancy to full term. Statistics show that as many as $25 \%$ of Polish couples have difficulty conceiving a baby ${ }^{11}$. Infertility is not just a contemporary problem, as it affected

9 Bible quotes, unless otherwise stated, come from The New American Standard Bible (NASB).

10 On Elephantine (a Jewish colony in Egypt, which developed particularly from the 5 th century $\mathrm{BC}$ ) some marriage certificates were found. These contained stipulations about the monogamous character of marriage. See more E. G. Kraeling, The Brooklyn Museum Aramaic Papyri: New Documents of the Fifth Century B.C. from the Jewish Colony at Elephantine, New Haven 1969; A. R. Morrow, I Hate My Spouse: The Performative Act of Divorce in Elephantine Aramaic, “Journal of Northwest Semitic Languages" 43 (2017), p. 7-25.

11 Dom - rodzina - małżeństwo, red. J. J. Pawlik, Olsztyn 2013, p. 29. 


\section{Marcin Majewski}

biblical married couples too. A lot of biblical stories are based on the theme of infertility. Today's infertile couples may find meditating on the situations of those married beset by the problem very helpful. In these stories contemporary couples may discern their own struggles and problems. Each one of the biblical stories of infertility is different, and each one may offer some optimistic threads.

The very beginning of the history of salvation focuses on the problem of infertility. The history of the patriarchs is for the most part a story of infertile women. The matriarchs of Israel in the Book of Genesis - Sarah, Abraham's wife; her daughter-in-law Rebekah; Jacob's wife Rachel - for many years experienced difficulty becoming pregnant. The problem also afflicted Samson's unnamed mother; Samuel's mother Hannah; Mary's mother Anne (which we know from the apocrypha); and Elizabeth, the mother of John the Baptist. The situation of these and other barren women was compounded by the fact that in the times of the First Testament childlessness was a socially condemnable state. In ancient Israel, where ancestral considerations played a crucial role, and numerous offspring was looked upon as God's special blessing, childlessness was regarded as disgrace and not infrequently equated with God's punishment. A woman's situation was all the more difficult that she was the only one to be blamed for infertility (hence the above-mentioned efforts to find a concubine for the husband made by the wife) ${ }^{12}$. Men were never blamed, for they were not faulted for the absence or loss of pregnancy.

As early as the beginning of the discussion of infertility in the First Testament a serious problem appears. All the examples of barren women in the Bible that I have mentioned so far were situations in which ultimately - as a result of God's intervention - a baby was born. After many years of suffering, the married couple, but above all the woman, was able to enjoy the longed-for progeny (cf. Gen 21:6 for Sarah's joy; or 1 Sam 2 for Hannah's prayer). Still, in everyday life not every case of infertility is resolved and crowned by conception and birth. The biblical authors choose positive examples, because they are focused on facts

12 K. White, The Legal Status of Barren Wives in the Ancient Near East, "Priscilla Papers" 28 (2014), p. 18-22. 
crucial for the history of salvation, and not on the sociological approach to society and its manifold problems. In their output they use the wellknown ancient literary topos whereby a child that is born under special circumstances - e.g. amid the drama of the infertility remedied by gods will later on become someone special entrusted with a foremost role. Paradoxically, in the Bible a mention of a lack of progeny serves as evidence of God's special plan for a given married couple. Such was the case of all the above-mentioned women. The pages of the Bible also carry examples of sterile women. However, these are invoked by hagiographers only in the context of the following pattern: having children $=$ a divine blessing, a lack of children = absence of divine blessing. Such is the situation of King David's wife Michal, who spurned the God-fearing king dancing in front of the Ark of the Covenant, as a result of which "Michal daughter of Saul had no children to the day of her death" (2 Sam 6:23).

The Bible testifies that sterility causes a married couple a lot of suffering (See Gen 15:20). "Give me children, or I'll die!" - cried Rachel to her husband Jacob (Gen 30:1). Hannah, the wife of Elkanah, "went up to the house of Lord... wept and would not eat" (1 Sam 1:7-10). More often than not, contemporary married couples who suffer from infertility or sterility experience loneliness, break off contact not only with their friends, but also with the family, with all those who have little children, shutting themselves off from the outside world. Childless individuals feel they are different than those who have children - they wish to fulfil their desire, but there is nothing they can do. It is a real trial to their faith. The First Testament confirms that infertility is a tough trial to a married couple. As for infertility, and especially sterility, when the husband and wife know that they will not be able to have their own children, the subject needs to be viewed from a wider perspective of fertility and fruitfulness in general - in life, which can be lived in a variety of ways. We need to ask questions about the fruitfulness of our lives as such. The Bible, and especially the Gospel, show that physical sterility is not absolute evil. Human life can become fulfilling in a number of ways. In Familiaris consortio, an exhortation addressed to families, John Paul II writes: "It must not be forgotten however that, even when procreation is not possible, conjugal life does not for this reason lose its value. Physical sterility in fact 


\section{Marcin Majewski}

can be for spouses the occasion for other important services to the life of the human person, for example, adoption, various forms of educational work, and assistance to other families and to poor or handicapped children" (Familiaris consortio, no. 14).

\section{Faithlessness, Infidelity and Betrayal}

In the First Testament, the concept of "betrayal" (the noun being הדיגב, and the verb being דגב does not so often appear in marital relations as in the relation between God and man. However, here I will focus on the marital betrayal. The biblical lawgiver explicitly and severely condemns marital betrayal (See Lev 20:10 and Deut 22:22). Both the perpetrators are to be punished by death. Compared with the "eye for an eye" principle, the punishment for betrayal was not proportionate to the offence, but much more severe. Such a radical sanction served to emphasise the fundamental relevance of the law on marital fidelity for the family and society. Here, betrayal is regarded as almost an act of murder of marriage. Still, it is noteworthy that in such cases death penalty was not performed. The provision of "are to be put to death" was to testify to the earnestness of the given directive. The matter of marital betrayal is in the Hebrew Bible so vital that it made its way into the Ten Commandments as the sixth commandment: ${ }^{13}$ "Thou shall not commit adultery". This prohibition is placed between the ones concerned with killing and stealing, that is between the gravest offences against the neighbour.

In the Book of Proverbs we can find a poetical invitation to fidelity, and condemnation of infidelity (See Prov 5:15-20). In the first part of the book (Prov 1-9) we can frequently come across words of caution directed at young men, whereby they are warned of seduction by a woman

13 The sixth one in the Catholic division of the Ten Commandments, because Jews (Philonic and Talmudic division) and Protestants (Lutheran division) divide the Ten Commandments in in a manner different to the one adopted by Catholics (Augustinian division). 
unfaithful to her husband. She is called a "wayward" (Hebrew הרז השא) wife, which simply means that she is a wife of another man (Prov 2:16-19; 5:2-14; 6:23-7:27). ${ }^{14}$ Such love leads to death (Prov 2:18;5:5; 7:26-27), which in this case is synonymous with moral doom. As a sin, betrayal puts such a strain on marriage that it entitled people of the First Testament to divorce, that is definitive rejection of a spouse (read about divorce below).

The mechanism of marital betrayal is a recurring pattern described already on the first pages of the Bible, in the story of the temptation of Adam and Eve in the Garden of Eden. The third chapter of the Book of Genesis features a description of the mechanism of sin, including betrayal. It shows the degrees of entering dialogue with evil, and the stages of yielding to temptation until the ultimate fall. The devil above all strives to break the conjugal unity; to draw the spouses away from God and to depict His commandments as too difficult; last but not least, to fascinate and enchant them with the forbidden fruit ${ }^{15}$. The effect of engaging in dialogue with evil, denying the image of God, making light of sin and delighting in the proximity of temptation is unavoidable - it is a downfall. Such a mechanism of sin is easily discernible in the story of David and his sin committed with Bathsheba (2 Sam 11:2-5). The author makes the first suggestion about David's deplorable conduct in the preceding verse: "In the spring, at the time when kings go off to war, David..." Irrespective of whether they were aggressors or the attacked one, in the event of military operations it was the kings who headed their armies. In this case, however, the protagonist acts strangely: he stays at home, lounging about on his bed, while his army is fighting in the battlefield. David, instead of being in the place associated with his role and predispositions, is strolling around the terrace. He sees a beautiful woman, whereupon a seed of passion sprouts up in him. Instead of resisting the woman, he inquires about her, thereby ending up in thrall to passions. The thought about Bathsheba keeps nagging him, and so he has her brought over for a sin of adultery. David's downfall triggers a succession

14 Some conjecture that it might be about a woman from a different nation, a pagan. To others, she is a woman of easy virtue.

15 A. Schüle, Die Urgeschichte (Genesis 1-11), op. cit., p. 88. 


\section{Marcin Majewski}

of sins: lies and intrigues which lead up to the arranged murder of Uriah, a magnificent warrior. The lesson to be learnt from this scene is that an unbridled emotion quickly turns into desire, which in turn changes into action. In the process the perpetrator is ready to lie, plot and cheat everyone around to achieve his goal, or to stop the betrayal from being given away. The blindness is so intense that he will not discern the magnitude of his wrongdoing, is indifferent to the tears of his spouse, children, parents; to cover up the traces of his betrayal he is ready to stoop to even more ignoble deeds. The scene depicting David shows that a person who has become embroiled in the sin of adultery and sticks with the infidelity, is capable of freeing himself only through an outside occurrence or a person. In this case, it was the prophet Nathan who gave succour to David, admonishing him. It was only the king's trusted adviser who made him realise the enormity of his sin, though he did not do it directly, but through a fable - a legal parable - so as not to risk being killed by the monarch overwhelmed with lust (See 2 Sam 12).

Also, the issue of forgiveness of betrayal appears in the Hebrew Bible. Here, we touch upon a very sensitive and complex issue. Forgiving marital betrayal should be unconditional, unqualified and ultimate - that is the way God forgives Israel their betrayal (Hos 3:1; Jer 31:20). Forgiveness should be granted irrespective of whether the unfaithful spouse returns and shows remorse, or leaves, adding to the damage. Such forgiveness, however, is a human act bordering on heroism and sacrificial love. One cannot request or demand it. It happens that a betrayed spouse feels such an inner block to overcoming their feelings that despite all the goodwill they cannot forgive or forget. The advice provided by the sage Sirach about forgiveness (See Sir 28:1-7) is very close to a New Testament attitude.

\section{Divorce}

The ancient world knew the institution of divorce very well. This applies to both the ancient Near East, that is the world depicted in the First Testament, and the Greco-Roman culture, that is the world depicted in the New Testament. Like in Mesopotamia, in Biblical Israel, marriage 
was a civil matter not sanctioned by any religious act. Admittedly, the prophet Malachi calls a wife "the wife of your marriage covenant" (דתירב תשא) (Mal 2:14), where תירב most often means a religious pact, but here the pact is nothing else but a marital contract. Marriage itself was a secular institution of a private character, with few religious elements present in the wedding ceremony. ${ }^{16}$

In the Old Testament a wife was not allowed to divorce her husband of her own accord. She could only file for a divorce, but the permission had to be granted by the husband. From a formal viewpoint it was only the husband who was allowed to send his wife away. That was the only thing permitted by the law (Deut 24:1) ${ }^{17}$. The rationale behind the divorce that was acceptable in the Book of Deuteronomy (Deut 24:1) was the fact that the husband had found something displeasing about her (רבד תורע, literally “a displeasing thing”). The phrase רבד תורע is very general and since ancient times it has been subject to a variety of interpretations as to what really might be the right reason for divorce. Etymologically (the verb הורע הרע) (הורע) the nouns a sexually shameful act, exposure of sexual organs, nudity, indecency or obscenity. The context of marriage probably points to adultery (exposing oneself to a stranger). Such an interpretation was adopted by Rabbi Shammai's rigorous school: the reason for divorce can only be infidelity or debauchery. A more laxist, and yet less biblical school of Hillel would settle for any reason, even one as trivial as when a woman failed to cook a good meal, or when a man just fancied some other woman. Sirach phrased the reason for divorce in yet another way: "If she will not do as you tell her, get rid of her" (Sir 25:26) - literally "cut her off from thy flesh" - that

16 It is only the post-exilic edited Book of Tobit that presents a highly religious vision of marriage as arranged by God (Tob 3:16), contracted under His eye, in faith and in the atmosphere of prayer (Tob 7:11; 8:4-9) on the basis of the model outlined in the Book of Genesis (Tob 8:6; cf. Gen 2:18), safeguarded against evil by everyday abiding by the Law (Tob 14:1. 8-13). See more: S. Shectman, What Do We Know about Marriage in Ancient Israel?, in: Reading a Tendentious Bible: Essays in Honor of Robert B. Coote, eds. M. L. Chaney, U. Y. Kim, A. Schellenberg, Sheffield 2014, p. 167-176.

17 C. C. Kroeger, The Biblical Option of Divorce, "Priscilla Papers" 13 (1999), p. 17-18; T. Eskenazi, Out from the Shadows: Biblical Women in the Postexilic Era, "Journal for the Study of the Old Testament" 54 (1992), p. 25-43. 


\section{Marcin Majewski}

is give her a bill of divorce. Again, the phrase "will not do as you tell her" is problematic, even though in all probability it may point to infidelity. Anyway, there is no doubt that both the Jewish law, and the later Roman law associated a possibility of divorce chiefly with an act of adultery, marital betrayal.

A similar situation appears to take place in the New Testament. An answer to whether Jesus absolutely forbids divorce is not as unequivocal as we have been led to believe by traditional interpretations. Admittedly, in the Gospels of Mark and Luke Jesus is explicit about prohibiting divorce, but a different light seems to be shed on the matter in the Gospel of Matthew, which twice features the following statement: "But I tell you that anyone who divorces his wife, except for sexual immorality, makes her the victim of adultery" (Matt 5:32; 19:9). Both of Jesus's statements contain an exception which, like in the law of the Torah, allows for sending away one's wife, that is for divorce. There, the exception

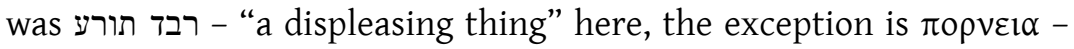

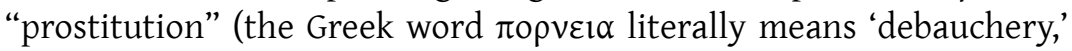
or 'prostitution'). These are the so-called Matthew's divorce clauses. The Catholic interpretation says that it is about dismissing an illegitimate wife, or about a separation, or marriage between close relatives, but not about a divorce. Others suggest that $\pi$ opvel $\alpha$ concerns a mixed marriage involving a pagan partner, contracted before conversion to Christianity (a frequent occurrence in the first Christian communities) as an invalidly contracted relationship ${ }^{18}$. Still, it must be admitted that the basic Greek meaning of the word $\pi$ opvela is closer to the notion of a prohibited sexual intercourse (adultery, prostitution, homosexual relations, relations with animals, premarital sex, intercourses with relatives, group sex; figurative "idolatry") than to intricate legal nuances. In all probability, the Matthew community - the most Jewish one - faced with the sanctity of marriage and in the spirit of the Book of Deuteronomy, recognised that such acts as adultery or infidelity were destructive to the relationship and thus authorised sending a spouse away (without specifying

18 See M. Kowalski, Powołani do życia w pokoju (1 Kor 7, 15). Lektura socjoretoryczna „przywileju Pawłowego" w 1 Kor 7, 12-16, “Verbum Vitae" 30 (2016), p. 121-152. 
whether a new relationship was permissible). Following this clause, Protestant Churches recognise that adultery ruins marriage, and allow for divorce under certain circumstances. Orthodox Churches understand these clauses similarly. Following other New Testament texts and the teachings of such Fathers as St Jerome, the Catholic Church assumes that there are no exceptions in the case of a validly contracted marriage.

Coming back to the issue of divorce in the First Testament, it should be noted that the biblical law imposed certain restrictions on the husband's powers to send his wife away. For instance, a man who falsely accused his wife of not being a virgin when he married her was not allowed to divorce her as long as he lived (Deut 22:13-19). The same applied to a man who violated a woman - he was to marry her and never send her away (Deut 22:28-29) ${ }^{19}$. A certificate of divorce had to be made in writing (Deut 24:1; Jer 3:8); just like a contract of marriage - the socalled ketubah (Tob 7:13). A woman who received such a certificate of divorce was allowed to remarry, and so was the man who submitted it. It is not known whether Jewish married couples exercised the right to divorce frequently. The prophetic and wisdom books extol conjugal fidelity (Prov 5:15-19; Eccl 9:9), which already at that time appeared to be the normal practice.

The most forceful statement that can be found in the First Testament against divorce is the one of Malachi (Mal 2:13-16). The prophet of the post-exilic era vehemently protests against the practice of divorce. He teaches that God Himself witnesses contracting a marriage: "The Lord was the witness between you and the wife of your youth". What is more, he calls the wife a "partner, the wife of your marriage covenant", citing the most important act of agreement in the Bible: the covenant between God and man (תירב). He is the only one to call marriage a covenant. Also, he calls the act of abandoning one's wife treason, betrayal and violence. Such offences were punished by death in the ancient state of Israel.

19 T. M. Lemos, Marriage Gifts and Social Change in Ancient Palestine, 1200 BCE to 200 CE, Cambridge 2010, p. 104, B. S. Jackson, The 'Institutions' of Marriage and Divorce in the Hebrew Bible, "Journal of Semitic Studies" 56 (2011), p. 221-251. 


\section{Marcin Majewski}

It would be difficult to find stronger words and images in condemnation of the institution of divorce in the Hebrew language used in the Bible.

In conclusion, the legal texts of the First Testament sanction the institution of divorce and with the right feel for fundamental justice regulate cases of a woman being taken advantage of by a man, prohibiting divorce in some cases. According to the Book of Deuteronomy (Deut 24:1), divorce was possible, but there had to a serious reason (fault) on the part of the wife. Recognised in the ancient world, this divorce-related practice overlaps with the teachings in the wisdom and prophetic writings, which on the one hand extol fidelity and permanence of matrimony, as well as teach about its indissolubility in a vivid manner, but on the other hand use harsh words to condemn the institution of divorce.

The above analysis of the main difficulties that biblical married couples in the First Testament grappled with leads to the conclusion that the ills and problems afflicting couples of that time are not so different from the ones besetting contemporary couples. Despite the great temporal and cultural distance, distinct similarities can be observed, which implies that some crisis mechanisms in marital relationships are universal. All the more justified is looking in the Bible for patterns and models for overcoming such crises. 


\section{Summary}

\section{The Four Problems which Old Testament Married Couples Grapple with}

In the context of a lively debate on the encyclic of Pope Francis Amoris laetitia, in this article I take up the four most important problems that marriages in the old Testament grappled with: polygamy, or marrying multiple spouses, lack of offspring, infidelity, or betrayal, and divorce. It is only against this issues that the profound novum of Catholic teaching on marriage emerges. The proposal will be that problems afflicting couples of biblical time are not so different from the ones besetting contemporary couples.

Keywords: Old Testament, marriage, polygamy, lack of offspring, betrayal, divorce

\section{Cztery problemy, z jakimi borykają się małżeństwa w Starym Testamencie}

W kontekście żywo dyskutowanej encykliki papieża Franciszka o małżeństwie Amoris laetitia w artykule podejmuję cztery najistotniejsze problemy, zjakim borykały się małżeństwa w Starym Testamencie: poligamia, brak potomstwa, niewierność czy zdrada oraz rozwód. Właśnie w tym kontekście ukazuje się w pełni specyfika katolickiego nauczania o matrymonium. Proponowana teza mówi, że problemy dotykające małżonków opisanych na kartach Biblii nie są odległe od tych, z którymi mierzą się dzisiejsze pary.

Słowa kluczowe: Stary Testament, małżeństwo, poligamia, brak potomstwa, zdrada, rozwód

\section{Bibliography}

Bielecki S., Stary Testament o małżeństwie. Ideał i rzeczywistość, "Kieleckie Studia Teologiczne" 2 (2003), p. 83-101.

Burnside J. P., Strange Flesh: Sex, Semiotics and the Construction of Deviancy in Biblical Law, "Journal for the Study of the Old Testament" 30 (2006), p. 387-420.

Marriage and Family in the Biblical World, ed. K. M. Campbell, Downers Grove 2003.

Drinkard J. F., An Understanding of Family in the Old Testament. Maybe not as Different from Us as We Usually Think, "Review and Expositor" 98 (2001), p. 485-501.

Eskenazi T., Out from the Shadows: Biblical Women in the Postexilic Era, "Journal for the Study of the Old Testament" 54 (1992), p. 25-43.

Friedl C., Polygynie in Mesopotamien und Israel: Sozialgeschichtliche Analyse polygamer Beziehungen anhand rechtlicher Texts aus dem 2. und 1. Jahrtausend v. Chr., Munster 2000.

Gross W., Die Gottebenbildlichkeit des Menschen nach Gen 1, 26.27 in der Diskussion des letzten Jahrzehnts, "Biblische Notizen” 68 (1993), p. 35-48. 


\section{Marcin Majewski}

Jackson B. S., The "Institutions" of Marriage and Divorce in the Hebrew Bible, "Journal of Semitic Studies" 56 (2011), p. 221-251.

Jacobus H. R., Slave Wives and Transgressive Unions in Biblical and Ancient Near Eastern Laws and Literature, in: "Leviticus and Numbers", ed. A. Brenner, A. Chi Chung Lee, Minneapolis 2013, p. 55-75.

Kiernikowski Z., Dwoje jednym ciałem w Chrystusie, Warszawa 2000.

Kowalski M., Powołani do życia w pokoju (1 Kor 7, 15). Lektura socjoretoryczna „przywileju Pawłowego" w 1 Kor 7, 12-16, "Verbum Vitae 30 (2016), p. 121-152.

Kraeling E. G., The Brooklyn Museum Aramaic Papyri: New Documents of the Fifth Century B.C. from the Jewish Colony at Elephantine, New Haven 1969.

Kroeger C. C., The Biblical Option of Divorce, "Priscilla Papers" 13 (1999), p. 17-18.

Lemos T. M., Marriage Gifts and Social Change in Ancient Palestine, 1200 BCE to 200 CE, Cambridge 2010.

Levine E., Marital Relations in Ancient Judaism, Wiesbaden 2009.

Meyers C., Rediscovering Eve: Ancient Israelite Women in Context, New York 2013.

Morrow A. R., I Hate My Spouse: The Performative Act of Divorce in Elephantine Aramaic, "Journal of Northwest Semitic Languages" 43 (2017), p. 7-25.

Otto E., Deuteronomium 12, 1-23, 15 (vol. 1) and Deuteronomium 23, 16 - 34, 12 (vol. 2), Freiburg 2016.

Dom - rodzina - małżeństwo, red. J. J. Pawlik, Olsztyn 2013.

Salzman T. A., Lawler M. G., The Sexual Person: Towards a Renewed Catholic Anthropology, Washington 2008.

Schüle A., Die Urgeschichte (Genesis 1-11) (Zürcher Bibelkommentare AT 1/1), Zurich 2009.

Shectman S., What Do We Know about Marriage in Ancient Israel?, in: Reading a Tendentious Bible: Essays in Honor of Robert B. Coote, ed. M. L. Chaney, U. Y. Kim, A. Schellenberg, Sheffield 2014, p. 167-176.

Shectman S., Rachel, Leah, and the Composition of Genesis, in: The Pentateuch: International Perspectives on Current Research, ed. T. B. Dozeman, K. Schmid, B. J. Schwartz, Tübingen 2011, p. 207-222.

White K., The Legal Status of Barren Wives in the Ancient Near East, "Priscilla Papers" 28 (2014), p. 18-22. 